【論 文】

UDC : $628.86: 62-79$
日本建築学会計画系論文報告集 第 420 号・1991 年 2 月 Journal of Archit. Plann. Environ. Engng, AIJ, No.420, Feb., 1991

\title{
温熱環境測定器としてのグローブ温度計の成立に関する研究 HISTORICAL STUDY ON GLOBE THERMOMETER
}

\author{
堀 越 哲 美*, 小林陽太郎**, 土川 忠 浩*** \\ Tetsumi HORIKOSHI, Yotaro KOBAYASHI and Tadahiro TSUCHIKAWA
}

The following transition of the globe thermometer was clarified.

A large ball made by Aitken was an archetype of a globe thermometer and originated in Leslie's sphere filled with warm water. Vernon finished the globe thermometer from the aspect of hardware and its application. Final completion was carried by Bedford and Warner. They gave a theoretical background to the instrument.

Keywords : globe thermometer, heat transfer, radiation, convection, history.

\section{1.はじめに}

室内温熱環境の計測器として使用されるグローブ温度 計は，直径 $15 \mathrm{~cm}$ の銅製黒叙り球である。主に熱放射 環境の計測に使用され，平均放射温度の算定や放射環境 の表現に用いられる。また；その示度は作用温度と近似 した值を示すとされている。このグローブ温度計は，あ る時点で突然発明されたものではなく，歴史的な発展過 程を経て成立してきた。本研究は，現在の温熱環境の評 価実務や研究で用いられているグローブ温度計の変遷と 成立過程を明らかにし、温熱環境測定・評価の歴史の中 での位置づけを行おうとするものであり，それとともに グローブ温度計に備えられた特性を技術史的側面から解 明しようとするものである。本研究では，それ自身に熱 源を備えていない，現在一般にグローブ温度計と呼ばれ ているものを対象とする。

\section{Leslie の温水球}

Bedford" ${ }^{11}$ によれば, 1804 年に Leslie は 4 in の錫製 の黒い球之磨いた球の 2 つの球の中に温水を満たしたも のを用いて, 各球の冷却から熱放射の効果を示した。一 方で，その磨き球の泠却力の観測から，風速を求める計 算式を導いている。そして; 球の部分が $1 / 2$ in 以上の 大きさである温度計を用いた風速計を提案している。そ の温度計の液はすみれ色のアルコールを用いるというも ので,カ夕寒暖計の原型に近いものであると考えられる。 この Leslieの開発した測定器は, 熱放射については温
度を測定するよりもむしら冷却力を取り扱うもので, 現 在のグローブ温度計それ自身とは異なった考ええ方であ る。それ故に，放射熱の計測とともに風速の計測法も開 発されたものと考えられる。この業績は, 黒い球を用い て熱放射の影響を測定した初めての試みであると考えら

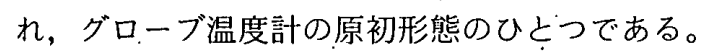

\section{Aitken の大球}

Aitken $^{21,3)}$ は，気温を日射の影響を除いて正確に測定 するために, 温度計に一定の気流が流れるような温度計 用の日射しゃへい装置を考案した。その一連の研究の中 で, Aitken ${ }^{4}$ 自身の考案になる C-screen ${ }^{i * 11}$ と. Stevenson の screen ${ }^{\sharp 21}$.の観測結果の比較から, 日射と風の状 態によって示度の差を認め, 熱放射と風の影響を表す測 定器の必要性に気付いた。このAitkenのデータより図 一1を作成した。Stevenson の screen による気温測定 とC-screen による気温測定との誤差は, 風力の增加に よって小さくなり,ほぼ反比例している。これは, 風速 の低い場合に日射の影響が出やすいことを示しているも のと考えられる。一方で, 乾球温度計や真空黒球温度計 の測定值だけでは，人間の温度感覚とあわなかったり， その地点の情報を十分には表していないことを指摘し て, 次のような測定器を考案した。それは, 中空の薄い 金属性の球拄 3 で，球の中心に温度計の球部がくるよう にしたものである。球の大きさについては, 余り小さく なければよいとして, 実際には直径 $15 \mathrm{~cm}$ と $40 \mathrm{~cm} の$

\footnotetext{
本論文は，日本建築学会東海支部研究発表会で口頭発表した内容に部正加䇦しまとめたものである。

* 名古屋工業大学 助教授・工博

** 豊橋技術科学大学 名誉教授・ T博

*** 岐阜工業高等専門学校 助手·工修

Assoc. Prof., Nagoya Institute of Technology, Dr. Eng.

Emeritus Prof., Toyohashi Univ. of Technology, Dr. Eng.

Research Assoc. of Gifu National College of Technology. M. Eng.
} 


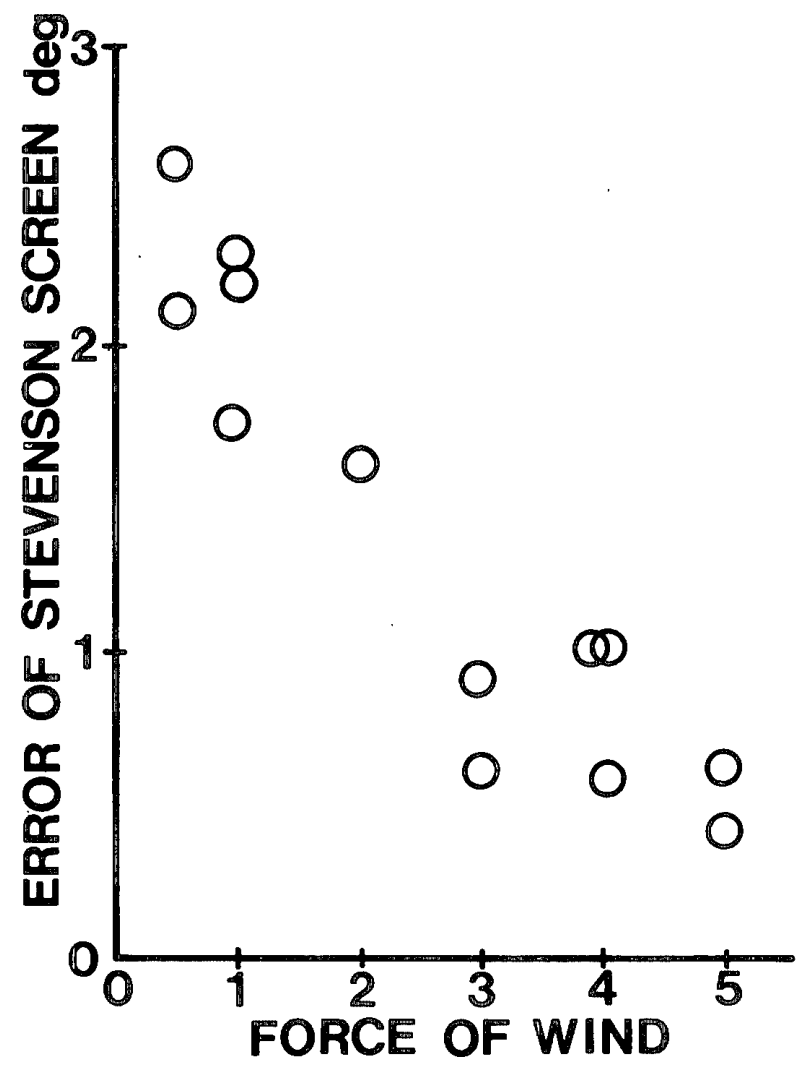

図一1 Aitken の実験による風力とStevenson Screen の誤差と の関係

2 種類の大きさを採用している。両者の温度計の同一条 件下での差は“わずか 2 3 度” $15 \mathrm{~cm}$ の方が低いとし ている。この差が球の大きさの影響であることは疑いな いものであると考えられる。球の対流熱伝達率は，その 直径が小さいほど大きいので, 直径の小さい球の方がそ の示度は低くなる。この点の掘り下げが不足していたと 考えられる。しかし，これは正にグローブ温度計の原型 である。しかも直径 $15 \mathrm{~cm}$ が採用されていた事実は興 味深い。この球の温度と気温との差を Aitken $^{4}$ は, 大 球による放射 (Radiation by large ball) と称し，熱放 射をとらえていることを示している。しかし，球の温度 そのものには深く言及していない。Stevenson の screen とC-scree との差 $\Delta t_{c}$ の議論を行うのに, 次式 にて表される量 $A$ を用いて評価を行っている。

$$
\begin{aligned}
& r=\Delta t_{g} / \Delta t_{v} \cdots \cdots \cdots \cdots \\
& A=\Delta t_{g} r=\Delta t_{g}^{2} / \Delta t_{v} .
\end{aligned}
$$

ただし

\section{$t_{g}:$ 球の温度 $\left[{ }^{\circ} \mathrm{C}\right]$}

$t_{v}:$ 真空温度計の示度 $\left[{ }^{\circ} \mathrm{C}\right]^{\text {i:4 }}$

この $A$ と $\Delta t_{c}$ との関係はほぼ比例関係にあるとして， この問題は解決できたとした。このデータを図化してみ ると, 図一2 が得られる。真空温度計と気温との差に対 する large ball と気温の温度差が, Stevenson screen と C-screen との誤差に比例するのは風力の弱い範囲で, 風力が強くなれば風の効果が卓越し，ほぼ一定值となっ

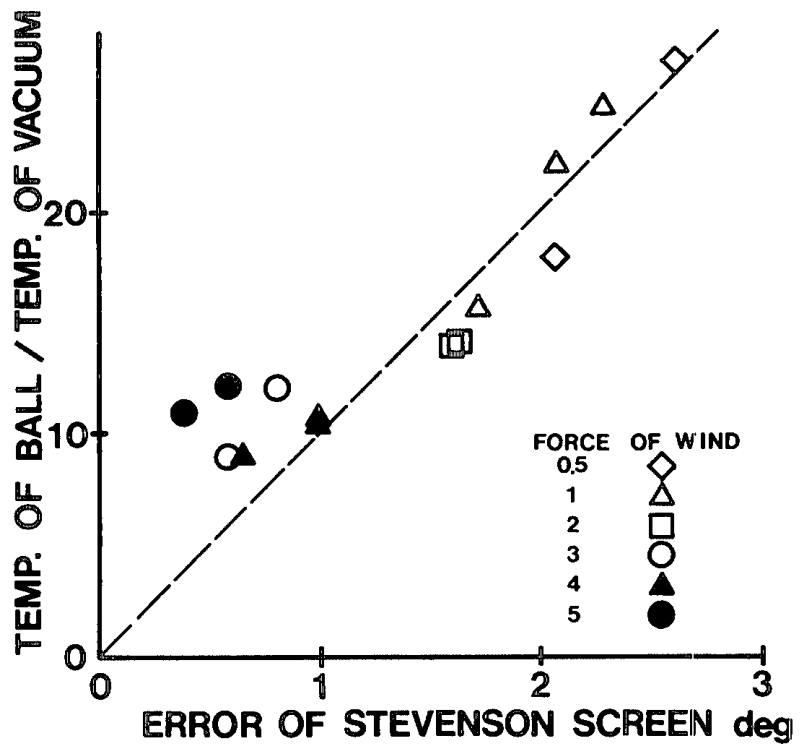

図一2 Aitken の実験による Stevenson Screen の誤差と真空温 度計注4)示度に対する大球の温度の比との関係

ていると解釈するのが妥当である。1911 年の発表論文 ${ }^{51}$ では, 1887 年の諭文が再掲されており， large ballによ る熱放射効果の測定について本質的な変化はみられな い。

\section{Vernonのグローブ温度計}

H.M.Vernon ${ }^{6}$ は，1930 年に発表した論文で Aitken の 2 種の径の球による日射の観測の実施を引用し，その 後のフォローが行われていないことを指摘した。本論文 はグローブ温度計による室内での熱放射環境の計測であ る。Vernon は, Aitken の業績は観測の事実のみ述べ, 自分の研究との関係は言及していないが, Aitken の研 究の引用を行ったことは，その影響下にあるものと考沉 られる。

このVernon の論文では，部屋のガスファイアーやス トーブからの“positive”な熱放射および令たい空なよ゙ からの “negative”な熱放射についての測定を行うため に，グローブ温度計 (Globe thermometer) を用いた。 この時点では, 球は表一 1 に示した直径と材質を持つ材 料によって作られた。現在使用されている銅製の球はま だ用いられていなかった。その中空球の中心に温度計を 挿入してグローブ温度計とした。これらのグローブ温度 計を用いて，静穏気流 $(3.6 \mathrm{~m} / \mathrm{min})$ と流動空気 $(82$ $\mathrm{m} / \mathrm{min})$ の 2 つ風速条件下での測定と，日射がある屋

表一1 1930 年の Vernon の実験に用いられたグローブ温度計の

\begin{tabular}{|c|c|c|c|c|c|c|c|}
\hline 面经 & 布地张り & その゙ー & $\begin{array}{l}\text { ル䩚 } \\
\text { 日リネン }\end{array}$ & 照ヘルヘット & $\begin{array}{l}\text { 黑球日的 } \\
\text { 渴度郎 }\end{array}$ & 黑望ガラス & $\begin{array}{l}\text { 通沮度 } \\
\text { 竍布湿り }\end{array}$ \\
\hline $0.7 \mathrm{~cd}$ & - & - & - & - & - & - & 0 \\
\hline $6.3 \mathrm{cD}$ & - & - & - & - & 0 & - & - \\
\hline $15.2 \mathrm{cn}$ & $\mathrm{O}$ & 0 & 0 & 0 & - & 0 & - \\
\hline $22.5 \mathrm{co}$ & 0 & 0 & - & - & - & -- & - \\
\hline
\end{tabular}
直径亡材質 


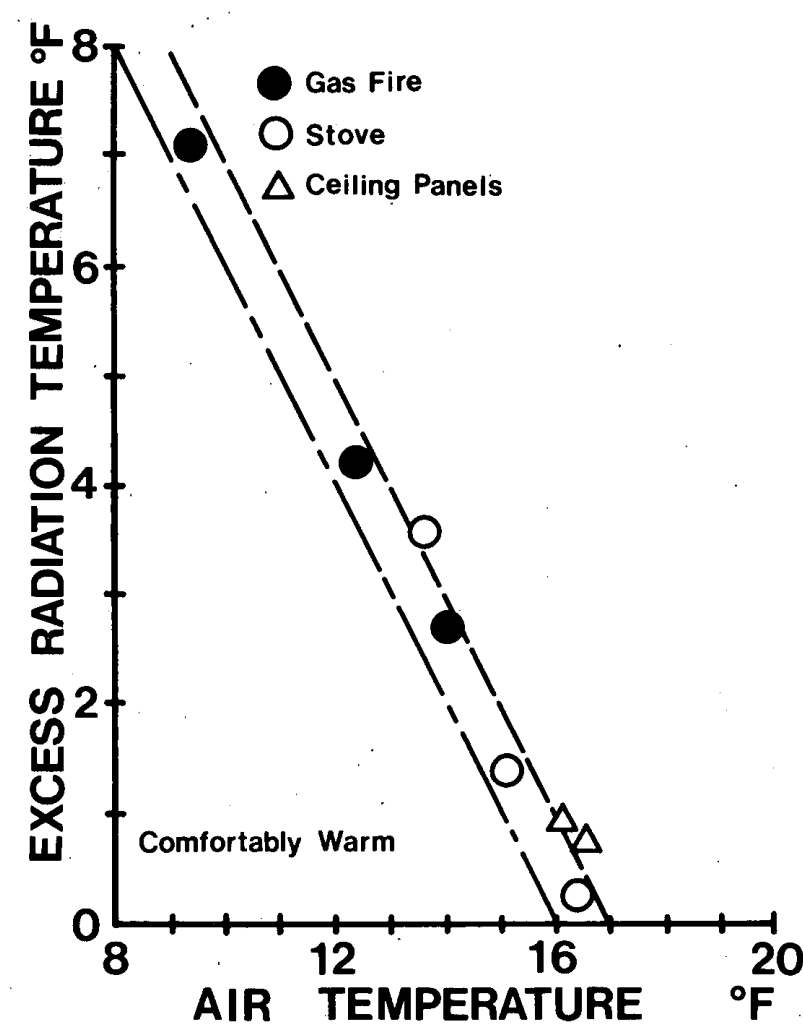

图一3 Vernonの実験による “Comfortably Warm” の申告の 場合の気温と超過放射温度との関係

外条件下での測定を行った。この実験結果から，クロス 張りのグローブ温度計よりつや消しのグローブ温度計の 方がわずかに低い温度測定結果を得た。ガラスフラスコ のグローブ温度計と $22.8 \mathrm{~cm}$ ボール紙のグローブ温度 計とでは，ガスファイアーの環境下ではほぼ等しいが， 日射環境下では，ガラスフラスコが $2^{\circ} \mathrm{C}$ 低い結果を得 ている。そして, $22.8 \mathrm{~cm}$ のグローブ温度計は $70 \mathrm{~kg} の$ 人体の表面積と体積の関係を持ってお゙り脑5)，最良であ ろうとしている。人体のモデルとしてグローブ温度計が 意識されていたことが明らかである。ここで，熱放射の 影響を示す量としてグローブ温度計の示度から気温を差 し引いた，超過放射温度 (Excess Radiation tempearture）を採用している。つぎに，グローブ温度計の示 度と人体の温冷感との関係についての実験を行った。2 名の被験者が (着衣状況は不明), comfortably warm の 申告をするための，ガスファイアー，ストーブ，天井パ ネルと人体との距離および気温との組み合わせの条件を 測定している。Comfortablè の申告が得られる条件を求 めるのではなく, Comfortably warm の条件を求めた点 が，暖かい側に暖房の意義があるという思想があるので はないかと推察される。その時のグローブ温度計の示度 を放射-対流温度 (Radiation-Convection temperature) と称して, 温冷感との対応関係がよいという結果を示し ている。この実験時の放射-対流温度は平均で $16.6^{\circ} \mathrm{C}$ であった。この実験結果に基づいて著者が作成したのが 図一3である。Comfortably warm の申告があった気温
表一2 1932 年の゙ Vernon の実験に用いられたグローブ温度計の 直径と材質

\begin{tabular}{|c|c|c|c|c|c|c|}
\hline 直经 & 暗布張り & $\begin{array}{c}\text { ボ } \\
\text { 黑ペンキ }\end{array}$ & $\begin{array}{l}\text { ル 䩚 } \\
\text { 白リネン }\end{array}$ & $\begin{array}{c}\text { カj } \\
\text { 暗布張り }\end{array}$ & ラ & $\begin{array}{c}\text { 銅 } \\
\text { 黑ペンキ }\end{array}$ \\
\hline $0.3 \mathrm{in}$ & - & - & - & 0 & 0 & - \\
\hline $2.5 \mathrm{in}$ & - & - & - & 0 & 0 & - \\
\hline 6 in & 0 & 0 & 0 & - & 0 & 0 \\
\hline 9 in & 0 & 0 & - & - & - & - \\
\hline
\end{tabular}

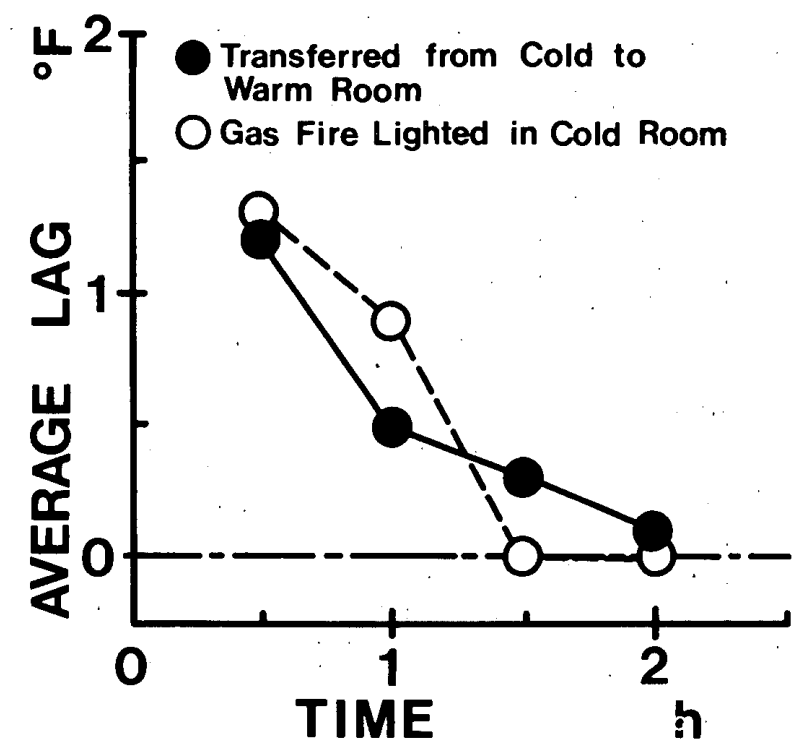

図一4Vernon の実験によ゙る環境が急変した場合のグローブ温 度計の平均表面温度と球内温度計のラグの時間的変動

と超過放射温度（=放射対流温度-気温）の組み合わせ をプロットした。図中の破線と一点鎖線は, 等グローブ 温度 $16^{\circ} \mathrm{C}$ と $17^{\circ} \mathrm{C}$ 線である。これは,グローブ温度ほ ぼ $16.5^{\circ} \mathrm{C}$ が Comfortably warm に対応していることを 示している。気温と放射温度の組み合わせであるグロー ブ温度が人体の温感と良く一致している。天井パネルで は，風速が他の条件より速かったので高い值を示してい ると結論しているが，それほどの差ではないと考えられ る。

1932 年発表の Journal of Industrial Hygiene $の$ 論文 ${ }^{71}$ で登場したグローブ温度計の直径と材質を表一 2 に示 す。ここに至って銅製のグローブ温度計が初めて現れた。 この論文では写真は示されていない。これは,ボールコッ クを利用したものである。新しい事項としては，グロー ブ温度計の測定タイムラグと表面温と内部の温度計との 温度ラグの問題である。銅製グローブ温度計は, 9 in クロス製よりも高い示度を示した。気流が過渡的に変化 する実験の結果銅製グローブ温度計はガラス製グローブ 温度計よりも速いタイムラグを持ち 15 分以下であると の結論を示している(46)。グローブ温度計の内外温度差 については，グローブ温度計を回転ロッドに取り付けモ ルサーモパイルで表面温度を測定した。この結果を著者 らが図に作成したものが図一4である。静止したグロー 
表一3 1933 年の Vernon の実験に用いられたグローブ温度計の 直径と材質

\begin{tabular}{|c|c|c|c|c|c|}
\hline 面经 & 暗布张り & $\begin{array}{l}*-N \\
\text { 黒ベンキ }\end{array}$ & 白リネン & $\begin{array}{l}\text { カラ } \\
\text { 黑ペンキ }\end{array}$ & $\begin{array}{c}\text { 銅 } \\
\text { 黑ペンキ }\end{array}$ \\
\hline $0.3 \mathrm{in}$ & - & - & - & 0 & - \\
\hline $2.5 \mathrm{in}$ & - & - & - & 0 & - \\
\hline 6 in & 0 & 0 & 0 & 0 & 0 \\
\hline 9 in & 0 & - & - & - & - \\
\hline
\end{tabular}

ブ温度計でも同様の結果を得ている。1930 年の報告で は超過放射温度 (Excess Radiation Temperature) と 称していたグローブ温度と気温との差を有効放射温度 (Effectual Radiation Temperature) と呼ぶことにして いる。1932 年の IHVEの Proceedings に発表された論 文齐では, ボールコックにチューブを半田付けし，ゴム 栓のふたに温度計が入れられていると詳しい説明と写真 で銅製のグローブ温度計が紹介されている。この論文で は, グローブ温度計の表面温度分布について詳しく述べ られている。クロス張りグローブ温度計の中に木綿綿を 詰め表面温度分布が測定された。実験条件は,ガスファ イアーの熱放射源と冷たい空がある場合で, 球上の温度 分布が示された。さらに，この不均一な熱放射条件下で 被験者を用いて実験を行い, 人体着衣左右表面温, 左右 の煩の表面温度が測定され，グローブ温度計表面の温度 と対応していることが述べられている。グローブ温度計 とモルサーモパイルがあればこのような環境を測定でき るとしている。非対称熱放射環境の人体影響に関する試 掘的な研究であったと評価できると考えられる。

日射環境の測定に関する研究 ${ }^{91}$ は1933 年に発表され ている。屋外で, 透明なガラス日射温度計, 黒塗日射温 度計と銅製グローブ温度計を用いて比較実験を行った

(表一 3 参照)。黒塗日射温度計とグローブ温度計との 超過放射温度の比率を $81: 100$ と算定した。この研究の 中で重要な点は, 球内の空気の影響について検討してい ることである。ガラスフラスコと銅製のグローブ温度計 に挿入された温度計の位置を球中心よりそれぞれ 1 in 上方または下方へずらせておき, 温度測定を行っている。 ガラスフラスコでは $6.9^{\circ} \mathrm{F}$, 銅球では $1.3^{\circ} \mathrm{F}$ の差であっ た。銅は熱伝導率が高いので有利であるとしている。球 内に空気があるか, 真空であるかの違いについては, 銅 製グローブ温度計では差がなく, ガラスフラスコは真空 にすることがよいという結論を得た。屋外における被験 者を用いた実験も行われている。着衣条件は, 灰暗色の 着衣と帽子の場合と白フランネルのズボン, 白リンネル のオーバーオールと帽子の 2 通りである。前者では銅製 グローブ温度計で, 後者では白りンネルで覆われたグ ローブ温度計で測定されている。Comfortably warm の 申告グローブ温度計は,それぞれ $73.4^{\circ} \mathrm{F}, 71.9^{\circ} \mathrm{F}$ であっ た。しかし，各々の奏験で黒グローブ温度計使用時には
白グローブ温度計の測定を，白グローブ温度計使用時に は黒グローブ温度計の測定を行っていない欠点がある。 カ夕寒暖計の冷却力もグローブ温度計の示度を用いるし 妥当な值が得られたとしている。そして，日射に対して もグローブ温度計は温冷感の良い指標になると結論し た。放射対流温度とEupatheo-scopeによる筷価温度

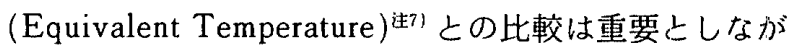
らも，実際の検証は行われていない。ただ，グローブ温 度計とEupatheoscope $\mathrm{i}^{111.12\rangle}$ の表面温度の差注8)によって, 放射源温度が低い場合には超過放射温度に差が出るこし を例解によって予测を行っている。

\section{Bedford とWarner によるグローブ温度計の解析}

Bedford と Warner ${ }^{1)}$ は，初めてグローブ温度計の熱 平衡式に基づいて理論的な裏付けを行った。グローブ温 度計の示度は，グローブ温度計と外界との間の缹放射交 換量 $H_{R}$ および対流熱交換量 $H_{C}$ による熱平衡次ら定ま る次式を示した。

$$
\begin{aligned}
& H_{R}=H_{C} \cdots \cdots \cdots \cdots \\
& H_{R}=E \sigma\left(T_{s}^{4}-T_{g}^{4}\right)
\end{aligned}
$$

ただし，

$E:$ 放射率（=0.95を採用）

$\sigma:$ ステファンの定数

$T_{s}$ : 平均放射温度 $\left[{ }^{\circ} \mathrm{R}\right]$

$T_{g}:$ グローブ温度計示度 $\left[{ }^{\circ} \mathrm{R}\right]$

$H_{\mathrm{c}}$ を求めるために, 直径 7 in の風洞を用いて、グロ一 ブ温度計内部に $100 \sim 111^{\circ} \mathrm{F}$ の温水を満たし, 気温 $40^{\circ} \mathrm{F}$ との差が数度になるまで冷却してグローブ温度計 の放熱量を求めた。対流熱交換量の計算式として次式を 得た。

$$
H_{c}=0.169 \sqrt{v}\left(t_{g}-t_{a}\right)
$$

ただし，

$$
\begin{gathered}
v: \text { 風速 }[\mathrm{ft} / \mathrm{min}] \\
t_{a}: \text { 気温 }\left[{ }^{\circ} \mathrm{F}\right]
\end{gathered}
$$

Bedford とWarner" は，低風速域では厳密に線形では ないことを指摘しているが, 議論を複雑にするのを避け た。実験が非定常で行われたことについては全く議論さ れていない。最終的に平均放射温度を求める次式を導い た。

$$
T_{s}^{4} \times 10^{-9}=T_{g} \times 10^{-9}+0.1028 \sqrt{v}\left(t_{g}-t_{a}\right)
$$

本式の速算用ノモグラムも作成されている。グローブ温 度計は熱放射算定の夹用的测定器であると結論してい る。

グローブ温度計の応用として, 等価温度 $E_{q} T^{11)}$ を求 める方法を提案した。これは，Eupathoscope ${ }^{121}$ が実用 的ではないので, より簡易に等価温度を算定しようとし た試みである。Duftonのデータを分析して，次の等価 
温度算定式を導いた。この間に熱放射算定式の線形化も 行っている。

$$
E_{\mathrm{q}} T=30+0.6 t_{s}-\left(75-t_{a}\right)(0.4+0.07 \sqrt{v})
$$

ここで,

$$
t_{s}=t_{g}+0.169 \sqrt{v}\left(t_{g}-t_{a}\right)
$$

Bedford とWarner は, 各種建物の実測データより, Eupatheoscope の等価温度とグローブ温度計から求め た等価温度は良く一致していた。彼らはグローブ温度計 と Eupatheoscope の形状，すなわち球と円筒，による 熱放射の指向性の違いについても指摘している。グロー ブ温度計の特性について, 人体の感覚よりも気流の影響 を受けやすいことを指摘し，グローブ温度計それ自身の みでは人体の温冷感の指標とはなりえないとし，具体的 欠点として次の 2 点を挙げている。

1）気温と壁温が等しい場合，風速のいかんにかかわら ずグローブ温度計の示度は変わらないこと。

2）周囲の壁温が気温よりも低い場合に, 人体では風速 が増加すれば当然対流による冷却力は大きくなるが，グ ローブ温度計ではその示度が上昇し気温に近付くという 現象が起きること。

これは，発熱体を持たない場合の宿命である。Bedford とWarner は述べていないが，気温が人体皮膚表面温よ り低い場合でなければならない。

\section{6. 湿度の影響の計測}

グローブ温度計は, “本来顕熱のみを取り扱うものとし て作られたが，同時代的に環境の湿度をも含めて体感温 度として測定しようとする試みが行われた。Missen$\operatorname{ard}^{131}$ は, Houghten とYaglou ${ }^{14)}$ の有効温度に熱放射の 影響を導入する合成温度の開発に関する一連の研究に続 いて, 合成温度の測定のために測定器を開発した。1934 年に, 直径 $9 \mathrm{~cm}$ の黒塗り球の乾き合成温度計 ${ }^{(5)}$ を発表 した。これは，4つの温熱環境条件のうち湿度の影響を 除いた体感温度である乾き合成温度を測定するものであ りここれは Vernon のいう放射対流温度である。ただ， この測定器の直径の決めかたはわからない。そして, 1935 年には水分蒸発とぬれ面積率が考虑された合成温 度計 ${ }^{16)}$ が完成する。これは, 直径 $9 \mathrm{~cm}$ の球表面の一部 にぬれた布を取り付けたもので，蒸発による冷却力が組 み入れられている点に特色がある。その後の Botsfo$\mathrm{rd}^{171}$ が開発したスポンジ状の球全体から水分を蒸発さ せて湿度の影響も考慮できるようにした湿りグローブ温 度計と異なり，一部分がぬれているというぬれ面積率の 考え方が導入されている点に独創性がみられる。ただ， Vernon からの影響は本研究では明確にはできなかっ た。しかし，同時代的にこの測定器が作られたことは少 なからぬ影響があったと考えられる。その意味でグロー
ブ温度計の開発の一連の流れの中にあると考えられる。 なお, Missenard ${ }^{17)}$ は, 球と同時に円筒形の測定器とサー モスタットも作成している。

\section{7. グローブ温度計の成立についての考察}

グローブ温度計の成立過程において, Leslie. は温水 を満たした黒球を用いて熱放射の効果を表そうとした が; 中空球を用いて熱放射と風の効果を測定しようとし たのは Aitken であった。球の大きさの影響についての 考察が不十分ではあったものの, 人間の感覚との関係に 注目したことは評価すべき点であると考えられる。放射 一対流温度の芽生えでもあり，グローブ温度計の原型が できたと判断される。Vernonは, グローブ温度計の材 質・寸法について詳細な検討を行い, ハードウエアーと しての 6 in の銅製グローブ温度計を完成させた。さら に, 表面温度分布・時間応答性や球内を真空にする意義 について実験的に確かめグローブ温度計の特性を明らか にし，実用への可能性を与えた。さらに，不均一な熱放 射環境や屋外での利用についての方法の提案と検討を 行った。このことは，現在も議論されている様々な利用 上の問題点や必要事項がほとんど指摘されて，当時の出 来うる限りのデータが出されていることを示している。 Vernonの業績は, 測定器としてのグローブ温度計の ハードウエアーの完成とその特性の実験的検討に基づい た利用方法の確立である。グローブ温度計は，ここでほ とんど完成したが, 伝熱理論的な裏付けは, Bedford と Warner の研究を待たねばならない。Bedford とWarner はグローブ温度計の熱平衡式を立て, 必要な球の熱伝達 式を実験を行って求め, グローブ温度計示度から求める 平均放射温度の式を導いた。さらに，等価温度の定式化 を行った。ここで，グローブ温度計に伝熱理論的な裏付 けが与えられ, 測定器としてのグローブ温度計の示度と 熱放射環境の表現である平均放射温度とが結び付けら れ, グローブ温度が測定器の示度から物理的環境指標と なった。これを以て真のグローブ温度計の完成というべ きであると考えられる。さらに, Bedford とWarnon は, 周囲壁温が気温と等しい場合および気温より低い場合に グローブ温度と人間の感覚が合わないことがあることを 指摘し，グローブ温度計の利用範囲と限界を明確にした 功績が評価される。さらに，グローブ温度計は人体の感 覚よりも気流の影響を受けやすいことの指摘は，その径 $15 \mathrm{~cm}$ が人体モデルとしては小さいことを意味してい る。しかし，グローブ温度から平均放射温度が算出でき る式を導いたことは，かなり簡便に平均放射温度を知る ことができ，これ以後の体感指標での熱放射の導入が容 易に行われたことに寄与したものと考えられ，歴史的に 評価できる。一方で, Missenardは, 同時代的にグロー ブ温度計の一部を湿らせて湿度の影響を取り入れ合成温 
度を測定する試みを行って, 総合的測定器への先鞭と なった。

\section{8. まとめ}

グローブ温度計は, Leslie の温水を満たした球を用 いた冷却力による熱放射の測定に端を発し，Aitkenの 中空の Large Ball に温度計を挿入して放射と風の効果 を測定する方法を経て, Vernonの材質・寸法の検討と その特性の実験検討でハードウエアーと使用方法が完成 し，Bedford とWarnerにより伝熱理論的な裏付けがさ れ，平均放射温度と結び付けられ真の完成に至ったこと を，技術史的に明らかにした。さらに，Missenard の湿 度を考虑した一種のグローブ温度計である合成温度計に ついても述べた。そして，この過程で明らかにされてき たグローブ温度計の特性や問題点についてまとめ上げ, その現代的な意義についての考察を行った。

\section{謝 辞}

本研究を行うに当たり，史・資料の入手について多大 なるご協力を賜った Saimon Faser 大学垣鍔直博士（当 時 Hawaii 大学), 豊橋技術科学大学附属図書館レフア ランスの皆様に心から感謝の意を表します。

注

1）文献 2)，3）中には直接的な C-Screen の名称は見あたら ないが, 浮力を利用した通風温度計の装置で掑氏温度計 用のものと考えられる。詳細図は文献 3) 参照。

2）方形で，その側面は 2 重のガラリ板のついたスクリーン である。

3）材質については明記されていない。

4）真空の黒塗りガラス球中に温度計が入れてある, 日射の 影響を測定する温度計。文献 2)に説明あり。

5）熱的には必ずしも等価ではない。

6)この 15 分という数字は, ガラスグローブ温度計との比較 実験のデータを基にしていて, 気温が変化している中で 行われたものである。

7) Eupatheoscope は Duftonにより考案された。この時点 では, Eupatheoscope は中空円筒でその表面を $75^{\circ} \mathrm{F} に$ 保つ放熱量に見合う, 気温二平均放射温度であり環境の 温度である等価温度を測定するものである。文献 11)，12) 参照。

8）文献 8)によれば,「Eupatheoscope（の表面温度は：著

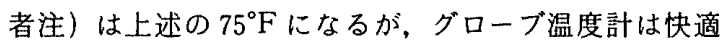
域で $62^{\circ} \mathrm{F}$ から $64^{\circ} \mathrm{F}$ に変化する。」

\section{既発表文献}

1）堀越哲美，小林踼太郎：グローブ温度計の成立について 一温熱環境評価方法の研究史 (1)一, 日本建築学会東海 支部研究報告, 第 21 号, pp. $281 \sim 284,1983$.

\section{引用文献}

1) Bedford, T. \& Warner, C. G. : The globe thermometer in studies of heating and ventilation, Journal of Hygine 34, pp. 458 473, 1934.

2) Aitken, J. : On thermometer screens Part I - II, Proceedings of Royal Society of Edinburgh xii, pp.661 696, 1883 -1884.

3) Aitken, J. : On thermometer screens Part III, Proceedings of Royal Society of Edinburgh xiii, pp. 532 -642, 1886.

4) Aitken, J. : Addition to thermometer screens Part IV, Proceedings of Royal Society of Edinburgh xiv, pp. $4: 28$ $\sim 432,1887$.

5) Aitken, J. : Radiation temperatures, Journal of Scottish Meteorological Society, 15(28), pp. 295 303, 1911.

6) Vernon, H.M. : The measurement of radian.t heat in relation to human comfort, Journal of Physiology 70, pp. xv xvii, 1930.

7) Vernon, H.M. : The measurement of radiation heat in relation to human comfort, Journal of Industrial Hygiene 14(3), pp. 95 111, 1932.

8) Vernon, H. M. : The measurement, in relation to human comfort, of the radiation produced by various heating systems, Proceedings of Institution of Heating and Ventilating Engineers, 31, pp.160 227, 1932.

9) Vernon, H.M. : The estimation of solar radiation in relation to its warming effect on the human body, Quartly Journal of Royal Meteorological Society 59, pp.239 252, 1933.

10) Dufton, A. F. : The Eupatheostat, Journal of Scientific Instruments 6, pp. 249 250, 1929.

11) Dufton, A.F. : The effective temperature of a warmed room, Philosophical Magazine 9, pp. 858 861, 1930.

12) Dufton, A.F. : The equivalent temperature of a room and its measurement, Building Research Station Technical Paper 13, pp. 1 9, 1932.

13) Missenard, A. : Température effective d'une atomosphere. Température résultant d'un milieu, Chaleur et Industrie XII(138), pp.552 557, 1931.

14) Houghten, F. C. \& Yagloglou, C.P. : deterraing lines of equal comfort zone, ASHVE Transactions 29, pp. 353 $\sim 360,1923$.

15) Missenard, A. : Considération sur l'efficacité des différents modes de chauffage, Chaleur et Industrie XV(174), pp. 278 300, 1934.

16) Missenard, A. : Théorie simplifiee du thermomètre résultant. Thermostat résultant, Chauffage-Ventilation Decembre, pp. 347 352, 1935.

17) Botsford, J. H. : A wet globe thermometer for environmental heat measurement, American Industrial Hygiene Journal 32, pp. 1 10, 1971.

（1990 年 2 月 6 日原稿受理, 1990 年 12 月 5 日採用決定） 